\title{
Medical robots in cardiac surgery - application and perspectives
}

\author{
Karolina Kroczek ${ }^{1}$, Piotr Kroczek², Zbigniew Nawrat ${ }^{1}$ \\ ${ }^{1}$ Department of Cardiac, Vascular, and Endovascular Surgery and Transplantology, SMDZ in Zabrze, \\ Medical University of Silesia in Katowice, Poland \\ ${ }^{2}$ Biocybernetics Laboratory, Zbigniew Religa Foundation for Cardiac Surgery Development, Zabrze, Poland
}

Kardiochirurgia i Torakochirurgia Polska 2017; 14 (1): 79-83

\begin{abstract}
Medical robots offer new standards and opportunities for treatment. This paper presents a review of the literature and market information on the current situation and future perspectives for the applications of robots in cardiac surgery. Currently in the United States, only $10 \%$ of thoracic surgical procedures are conducted using robots, while globally this value remains below $1 \%$. Cardiac and thoracic surgeons use robotic surgical systems increasingly often. The goal is to perform more than one hundred thousand minimally invasive robotic surgical procedures every year. A surgical robot can be used by surgical teams on a rotational basis. The market of surgical robots used for cardiovascular and lung surgery was worth 72.2 million dollars in 2014 and is anticipated to reach 2.2 billion dollars by 2021. The analysis shows that Poland should have more than 30 surgical robots. Moreover, Polish medical teams are ready for the introduction of several robots into the field of cardiac surgery. We hope that this market will accommodate the Polish Robin Heart robots as well.
\end{abstract}

Key words: surgical robots, cardiac surgery.

\section{Introduction}

Medical robotics encompasses manipulators and robots used in surgery, therapy, prosthetics, and rehabilitation. The goal of implementing surgical robots is to increase the effectiveness and reproducibility (standardization) of surgical procedures as well as to reduce their invasiveness. Robots are used for the telemanipulation of surgical tools: an endoscopic video system and/or endoscopic operating tools.

Robin Heart - a Polish family of surgical robots [1, 2] - is now at the beginning of its way into clinics. Do we stand a chance of implementing a Polish robot? Does cardiac surgery need robots? What kind of robots? Was it the right

\section{Streszczenie}

Roboty medyczne oferują nowe standardy i możliwości w zakresie leczenia. W pracy przedstawiono przegląd piśmiennictwa oraz informacji rynkowych dotyczących aktualnego stanu i prognoz rozwoju zastosowań robotów w kardiochirurgii. Obecnie w Stanach Zjednoczonych jedynie 10\%, natomiast w skali światowej mniej niż 1\% zabiegów chirurgii klatki piersiowej wykonuje się za pomocą robotów. Coraz częściej jednak torakochirurdzy wykorzystują zrobotyzowane techniki podczas operacji i cel 100 tysięcy zabiegów z zastosowaniem robotów rocznie - pewnie zostanie wkrótce osiągnięty. Robot chirurgiczny może być wykorzystywany w sposób ciągły przez rotacyjne zespoły wielospecjalistyczne w szpitalu. Rynek robotów chirurgicznych stosowanych w torakochirurgii był wart 72,2 mln dolarów w 2014 r. i przewiduje się, że osiągnie wartość 2,2 mld w 2021 r. Z przeprowadzonej analizy wynika, że w Polsce powinno być ponad 30 robotów chirurgicznych, a zespoły medyczne są przygotowane do wprowadzenia kilku robotów chirurgicznych w kardiochirurgii. Mamy nadzieję, że znajdzie się na tym rynku miejsce dla polskich robotów Robin Heart.

Stowa kluczowe: roboty chirurgiczne, operacje kardiochirurgiczne.

decision to start with a video system robot - Robin Heart PVA? These are the questions that gave rise to the deliberations described below.

Three models were developed during the first phase of the project [1]: Robin Heart 0, Robin Heart 1, and Robin Heart 2. Then, the first prototype of a robot for controlling an endoscopic video system was created - the Robin Heart Vision robot. In 2010, the multi-set, modular Robin Heart mc2 robot was implemented. In its full configuration, it is capable of replacing three people at the operating table the first and second surgeon and the assistant handling the video system. Mechatronic Robin Heart UniSystem tools

Address for correspondence: Assoc. Prof. Zbigniew Nawrat MSc, PhD, Department of Cardiac, Vascular, and Endovascular Surgery and Transplantology, SMDZ, Medical University of Silesia, 41-800 Zabrze, 9 M. Curie-Skłodowskiej St, Poland, phone: +48 607728664 , fax: + 4832 3735677, e-mail: nawrat@frk.pl

Received: 8.11.2016, accepted: 12.01.2017. 
were also developed - they can be quickly dismounted from the robot's arm and used manually with a special handle. Experiments conducted on animals in 2009-2010 proved the adequacy of the implemented structural solutions and control methods; the video system robot met all the expectations of the medical team [2, 3]. The first robot from the Robin Heart family is now being prepared for implementation; it is a light, single-arm, portable video system robot - hence the name: PortVisionAble (PVA).

\section{Global robot market}

Opportunities for expanding the use of robots in surgery are associated with the progress of surgical treatment (medicine) and technology (including robotics). An analysis of the medical market of the last few years, based on reports from the International Federation of Robotics, shows that medical robots constitute $5-10 \%$ of all service robots sold [4]. Despite the fact that medical robots constitute a small percentage of all robots sold, the sales value of medical robots constitutes approximately $40 \%$ of all service robot sales. Among the most expensive devices are robots used for soft tissue surgery (da Vinci) and radiosurgery (CyberKnife).

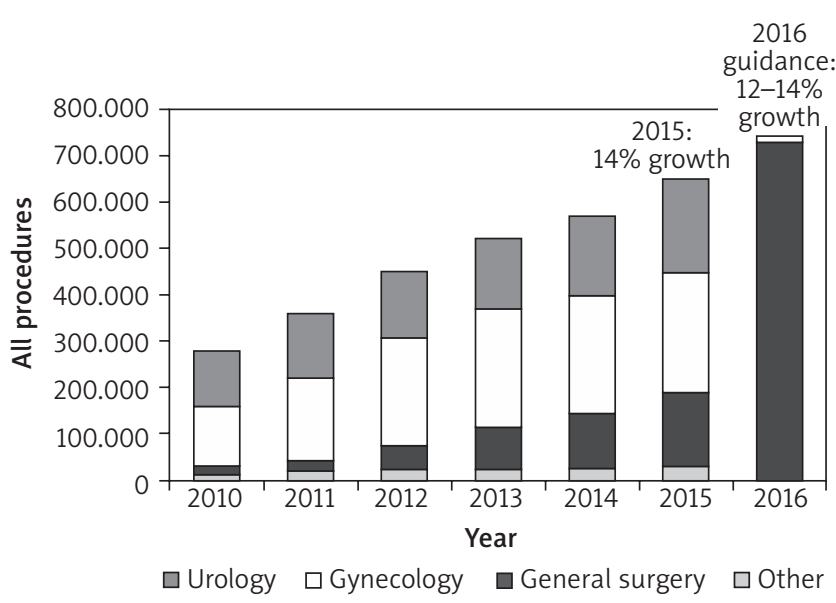

Fig. 1. Estimated number of all robotic procedures conducted in the years 2010-2015 [6]

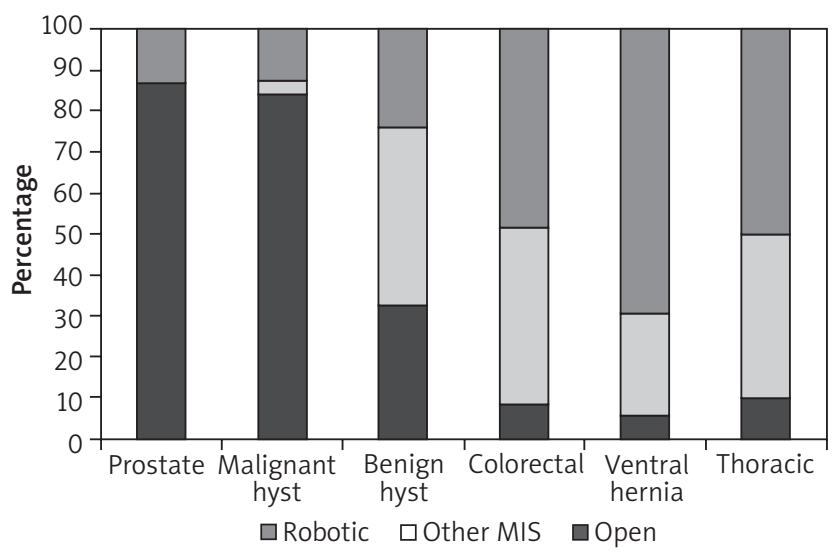

Fig. 2. Proportion of robotic procedures in individual medical procedures conducted in the United States in 2015 [6]
According to the forecasts of the International Federation of Robotics published in a report from 2015, 152400 professional service robots with a total value of 19.6 billion dollars with be sold between 2015 and 2018. This includes 7800 medical robots, which gives a yearly average of 1950 robots, indicating an increase of 750 in comparison to 2014 [4]. The analyzed reports predict that the compound annual growth rate of the global medical robot market will be $10-20 \%$ in the years $2015-2020$.

The medical equipment market is a rapidly growing sector of the economy. MedTechWorld prepared a ranking of one hundred medical equipment companies with the highest revenue in 2015 [5]. Eight of them were involved to some extent in medical robotics. The $29^{\text {th }}$ position in the ranking was occupied by Intuitive Surgical, the only company specializing in robotics only, which is now a monopolist on the surgical robot market.

The da Vinci robots are currently the only surgical robots approved by the American Food and Drug Administration for use in surgery (including various types of cardiac surgery). The first version of the robot appeared in 1999 , and the system has evolved since then. Four versions have been created so far: da Vinci Xi Surgical System, da Vinci Si Surgical System, da Vinci S Surgical System, and the basic version - da Vinci Surgical (currently being withdrawn) [6].

Over 3660 da Vinci robots have already been sold around the world; $65 \%$ of them are in the USA (data as of the second quarter of 2016 [6]).

In 2015 almost 652 thousand procedures were conducted using the da Vinci robots. The majority of surgical robots are used in gynecological and urological procedures (250 and 200 thousand procedures, respectively), where their effectiveness and superiority over classical methods have been proven numerous times. Figure 1 shows the increase in the number of procedures. In the United States, almost $90 \%$ of all prostatectomies and over $80 \%$ of hysterectomies involving malignant tumors are conducted with the aid of robots (Fig. 2).

Only $10 \%$ of all thoracic surgery procedures in the United Stated are performed using robotic techniques; on a global scale, it is merely $1 \%$. More and more clinical centers are making attempts to popularize robotic procedures, and new robots are being prepared to join the da Vinci series on the market.

\section{Analysis of scientific reports}

Literature reports concerning robotic cardiac surgery written in English in the last 5 years were subjected to a review using the PubMed database of medical articles, which was searched for the following terms from the Medical Subject Heading (MeSH) medical vocabulary resource:

- Robotic Surgical Procedures - surgical procedures conducted using computers remotely controlling surgical tools mounted on specially designed mechanical arms.

- Cardiac Surgery - the field of surgery focused on the diagnosis and treatment of heart diseases. 
The data concerning the number of robots used in the selected countries were acquired from publications by Intuitive Surgical from the second quarter of 2015 [6]. The data concerning the number of patients in Poland were acquired from the database of the Polish National Health Fund [7]. The data concerning the number of cardiac surgical procedures conducted in Poland and the methods used were acquired from KROK (Krajowy Rejestr Operacji Kardiochirurgicznych) - the Polish National Register of Cardiac Surgery [8]. The results collected were then analyzed in MS Excel.

A total of 46 results were obtained when searching for the terms "Robotic Surgical Procedures" and "Cardiac Surgery". Table I shows the number of PubMed articles in English from the past 5 years for each term.

Half of the results were publications from 2014, 22 of the articles were published in 2015, and only one was from this year. More than half of the articles focused on two types of procedures: coronary artery bypass grafting (CABG) and mitral valve repair (MVR).

Figure 3 shows a detailed division of all the analyzed articles with regard to their subject matter.

The most recent literature reports contain descriptions of long-term experiences of foreign centers in the use of robotic systems for various cardiac surgical procedures. Among other data, the articles presented CABG results, including robotic acquisition of internal thoracic artery (ITA) [9] and internal mammary artery (IMA) grafts [10], and comparisons of short- and long-term outcomes for various techniques [11, 12]. Results pertaining to MVR procedures were described by Algarni et al. [13], while Senay et al. [14] assessed the feasibility of procedures in patients with severe rheumatic valve insufficiency. Yang et al. [15] and Yanagawa et al. [16] compared robotic and non-robotic procedures, taking into consideration their complication rates, costs, and the length of hospital stays.

The vast majority of publications conclude that cardiac surgical procedures conducted using robots are feasible and safe. In general, robotic procedures are characterized by significantly shorter hospitalization, a reduced number of complications, and lower mortality in comparison to classic surgical techniques. The authors also pointed out that robotic procedures are associated with longer durations of the procedures and higher costs. More research should be conducted for some procedures in order to establish the limitations in the use of robots.

Apart from publications describing the direct clinical outcomes of the conducted procedures, there were also those concerned with the anesthesiological problems and challenges associated with the use of robotic techniques [17]. There were interesting publications on the application of medical image measurement techniques for establishing the anatomical features that may affect the duration [18] or chance of success of robotic surgical procedures [19].

Most publications provide very general information regarding the costs, only stating that robotic procedures are more expensive. Yanagawa et al. [16] made an attempt to conduct a more detailed comparative analysis of the dif-
Tab. I. Number of publications in the PubMed database concerning the listed MeSH terms (as of July 17, 2016)

\begin{tabular}{lc} 
MeSH term & Number of articles \\
Robotic surgical pocedures & 1287 \\
\hline Cardiac surgery & 31790 \\
\hline $\begin{array}{l}\text { Robotic surgical procedures AND cardiac } \\
\text { surgery }\end{array}$ & 46 \\
\hline
\end{tabular}

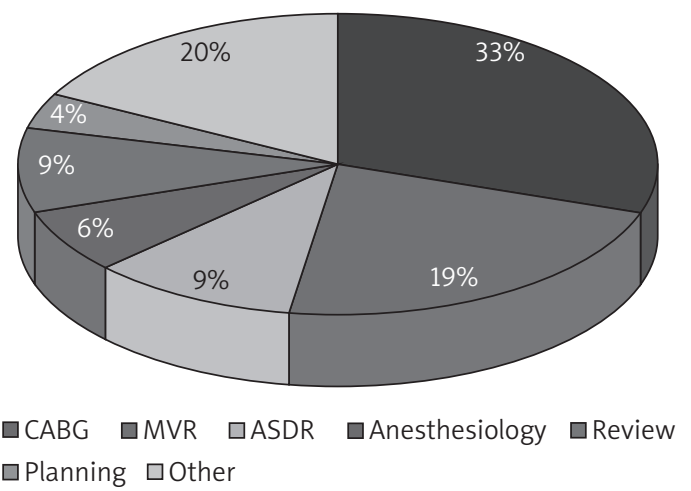

CABG - coronary artery bypass grafting, MVR - mitral valve repair, ASDR - atrial septal defect repair.

Fig. 3. Division of the analyzed articles with respect to the subject matter

ferences between robotic and non-robotic cardiac surgical procedures, comparing, e.g., their costs, mortality rates, and hospital stay durations. The comparison included procedures conducted in the USA within the previous 4 years. According to the data presented, robotic procedures were on average $10 \%$ more expensive than non-robotic procedures. The length of hospital stay, however, was 1-2 days shorter.

Bachinsky et al. [20] compared two groups of patients: a group undergoing hybrid CABG using a robot and a group undergoing off-pump CABG (OPCABG). Thanks to the use of robots, the hybrid CABG procedures lasted $2 \mathrm{~h}$ less on average when compared to the non-robotic procedures. Moreover, the hybrid procedures reduced intensive care unit (ICU) stay by $20 \mathrm{~h}$ and total hospitalization time by 3 days on average. Additionally, the patients undergoing the hybrid procedures experienced less blood loss. The costs of the hybrid procedures were much higher than those of OPCABG, partially due to the longer duration of the procedures themselves. Postoperative expenses, however, were $50 \%$ lower in the case of the hybrid procedures.

Jones et al. [21] also presented the results of comparative research concerning robotic and non-robotic CABG procedures, demonstrating that the use of robots in $C A B G$ reduces ICU stay as well as total hospitalization time.

According to KROK, nearly 27 thousand cardiac surgical procedures are currently conducted in Poland every year, only $23 \%$ of them employing minimally invasive methods [8]. Figure 4 shows the number of cardiac surgical proce- 


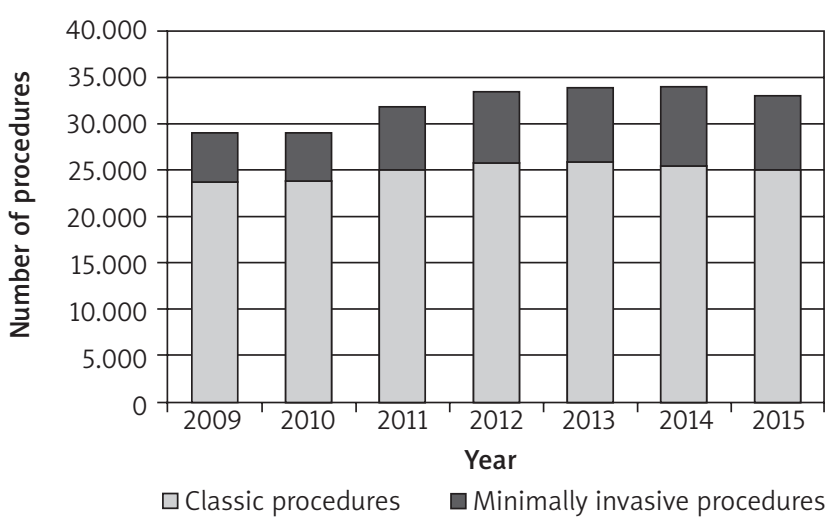

Fig. 4. Number of cardiac surgical procedures conducted in Poland between 2009 and 2015 together with the method applied (own work based on data by KROK [8])

Tab. II. Data concerning hospitalization of CABG patients in 20122015. Patients from groups E05-E06 [7]

\begin{tabular}{cccc} 
Year & $\begin{array}{c}\text { Number } \\
\text { of hospitalizations }\end{array}$ & $\begin{array}{c}\text { Duration } \\
\text { of hospitalization } \\
- \text { median [days] }\end{array}$ & $\begin{array}{c}\text { Average cost } \\
\text { of hospitalization } \\
\text { [PLN] }\end{array}$ \\
\hline 2012 & 13759 & 9 & 23201.69 \\
\hline 2013 & 13418 & 9 & 23443.34 \\
\hline 2014 & 13011 & 9 & 23494.88 \\
\hline
\end{tabular}

dures conducted in Poland, together with the methods applied. Adding up all types of cardiac surgical procedures, CABG constituted the vast majority ( $68 \%$ on average) of all procedures conducted in Poland in the years 2009-2015.

According to the statistics of the National Health Fund, the average value of hospitalization associated with coronary artery bypass grafting (E05-E06) was approximately PLN 24 thousand. The hospitalization of patients in the years 2012-2015 was approximately 9 days (Table II).

\section{Discussion and conclusions}

According to KROK, the Polish National Register of Cardiac Surgery [8], Poland currently has 38 clinics performing approximately 27 thousand cardiac procedures annually, including 7.5 thousand procedures conducted using minimally invasive methods (in 32 centers). Robotic cardiac surgery started with mitral valve surgery in 1998 (Loulmet-Carpentier in Paris and Falk-Mohr in Leipzig). It may, therefore, be assumed that most of the 278 minimally invasive mitral valve repairs taking place in 2015 could have been successfully conducted using surgical robots (at the moment, only the American da Vinci robots). Depending on the site of surgical intervention, some of the CABG procedures (minimally invasive OPCAB + MIDCAB + TECAB: 6665 in 2015) could have also been conducted using surgical robots. In order to achieve appropriate economic viability, a robot should be used almost daily - according to our estimations, 300 times during one year (at least three times more often than was the case with the first Polish da Vinci in Wroclaw, which was acquired thanks to the determination of Professor Wojciech Witkiewicz, but is not used frequently enough for financial reasons). The analysis indicates that medical teams are ready for the implementation of surgical robots into cardiac surgery.

The number of people per robot was also calculated for individual countries (the USA has 1 robot per 140 thousand inhabitants, but in the UK and the Czech Republic (!) there is currently 1 robot per 1.5 million inhabitants). The analysis averaged the data from countries with a high Human Development Index ( $\mathrm{HDI})$, excluding the extreme values from Poland and the USA, showing that assuming a ratio of 1 robot per 1.15 million population is reasonable considering the current usage of the da Vinci robot in many fields of surgery. This would mean that Poland should have approximately 34 robots, including 4 robots used in cardiac surgery.

Lets us now return to cardiac surgery and robots replacing the assistants handling the video system. According to statistics by KROK, 31 out of 38 cardiac surgery centers conduct minimally invasive procedures. It may, therefore, be assumed that most of the 152 operating theaters available in these centers would be able to use a video system robot. In 2017, we will make an attempt to implement the Robin Heart PVA video system robot, which could be used successfully in a fashion similar to the American AESOP robot (no longer produced), used by the pioneering team of Professor A. Bochenek in over 300 cardiac surgical procedures in Katowice (Medical University of Silesia). It is worth emphasizing that robotic surgery in Poland started with cardiac surgery - in the year 2000, Cisowski and Bochenek started using a voice-controlled AESOP robot for image control during videoscopic procedures. They also conducted almost 10 cardiac surgical procedures with a borrowed Zeus robot. Both robots were manufactured by Computer Motion, an American company which was subsequently assimilated by Intuitive Surgical, which ceased their production and currently offers the da Vinci robots only.

Most likely not all cardiac surgical procedures are suitable for the use of a fully robotic technique, but most endoscopic and minimally invasive operations (without full thoracotomy) can use a video system robot controlled directly by the surgeon. The Robin Heart PVA robot, designed by the Zbigniew Religa Foundation for Cardiac Surgery Development, is an answer to the need for a light, portable robot mounted on the side rail of a standard operating table. Both the robot and the settings of the operating table can be controlled with a convenient remote panel. A mini-joystick mounted on the endoscopic tool was designed as well. Using just one finger, the surgeon can adjust the position of the robot's arm and display the image of the current surgical site, located inside the patient's body, on a monitor via the video system.

One of the most frequently mentioned drawbacks of the use of robots in all types of surgical procedures is the high cost of purchase and use of such devices. The price of a single da Vinci system starts at 1 million dollars. The cost of obligatory maintenance (approximately 150 thousand 
dollars) and the set of tools and instruments, sufficient for 10 procedures only (700-3500 dollars), should also be taken into consideration. Apart from the direct costs associated with the device, the majority of cases require additional expenses resulting from the longer duration of procedures.

With respect to the cost of the procedure alone, non-robotic procedures may be up to $40 \%$ less expensive than their robotic counterparts. However, it should be noted that hospitals incur the entirety of the costs associated with hospitalization, including the time spent at the operating theater and the ICU as well as the remainder of the stay. The costs associated with potential complications, including reoperation, should also be included. The total costs of hospital stay in the case of robotic procedures are comparable, if not lower. Additionally, the lower rate of postoperative complications reduces the overall expenses incurred by the hospital.

We hope that the technological progress and popularization of robots will result in economic benefits and, most importantly, help meet the needs of doctors and their patients by reducing the invasiveness of cardiac surgery and allowing for its better standardization.

The market of surgical robots used for cardiovascular and lung surgery was worth 72.2 million dollars in 2014. According to forecasts [22], this value will reach 2.2 billion dollars by the year 2021, and the annual number of cardiac surgical procedures will soon increase to 100 thousand a year. Doctors and patients around the world will enjoy the benefits of this technological development. Operating theaters may be used by surgical teams on a rotational basis, which is a more economical solution. We hope that this market will accommodate the Polish Robin Heart robots as well. The first clinical trials of the Robin Heart PVA video system robot will begin shortly.

\section{Disclosure}

Authors report no conflict of interest.

\section{References}

1. Nawrat Z. The Robin Heart story. Medical Robotics Reports 2012; 1: 19-21.

2. Nawrat Z. Robot Robin Heart 2010 - raport z prac badawczych. Kardiochir Torakochir Pol 2011; 8: 126-135.

3. Nawrat Z. Robot chirurgiczny Robin Heart - projekty, prototypy, badania, perspektywy. Rozprawa habilitacyjna. Śląski Uniwersytet Medyczny, Katowice 2011.
4. Kroczek K. Rynek robotów medycznych. Medical Robotics Reports 2015; 4: 68-72.

5. Qmed. Top 100 Medical Device Companies of 2015. Available at: http:// directory.qmed.com/since-a-wave-of-megamergers-swept-the-medicalfile059049.html; accessed at: 15.01.2016.

6. Intuitive Surgical. Investor Presentation. Available at: http://www.intuitivesurgical.com/company/, 08.05.2016.

7. Narodowy Fundusz Zdrowia. Analiza przekrojowa. https://prog.nfz.gov.pl/ appjgp/AnalizaPrzekrojowa.aspx, 17.07.2016.

8. Rejestr głównych typów operacji kardiochirurgicznych w 2015 r. w poszczególnych ośrodkach w Polsce (wg Krajowego Rejestru Operacji Kardiochirurgicznych KROK, Warszawa, 2016). Kardiochir Torakochir Pol 2016; 13: 185-188.

9. Ishikawa N, Watanabe G, Tomita S, Yamaguchi S, Nishida Y, lino K. Robotassisted minimally invasive direct coronary artery bypass grafting. Circ J 2014; 78: 399-402.

10. Fujita T, Hata H, Shimahara Y, Sato S, Kobayashi J. Initial experience with internal mammary artery harvesting with the da Vinci Surgical System for minimally invasive direct coronary artery bypass. Surg Today 2014; 44: 2281-2286.

11. Leyvi G, Forest SJ, Srinivas VS, Greenberg M, Wang N, Mais A, Snyder MJ, DeRose JJ Jr. Robotic coronary artery bypass grafting decreases 30-day complication rate, length of stay, and acute care facility discharge rate compared with conventional surgery. Innovations (Phila) 2014; 9: 361-367.

12. Sabashnikov A, Patil NP, Weymann A, Mohite PN, Zych B, García Sáez D, Popov AF, Wahlers T, Wittwer T, Wippermann J, Amrani M, Trimlett R, Simon AR, Pepper J, Bahrami T. Outcomes after different non-sternotomy approaches to left single-vessel revascularization: a comparative study with up to 10year follow-up. Eur J Cardiothorac Surg 2014; 46: e48-e55.

13. Algarni KD, Suri RM, Daly RC. Robotic-assisted mitral valve repair: surgical technique. Multimed Man Cardiothorac Surg 2014; 2014. pii: mmu022.

14. Senay S, Gullu AU, Kocyigit M, Degirmencioglu A, Kilic L, Karabulut H, Alhan $C$. Robotic mitral valve replacement for severe rheumatic mitral disease: perioperative technique, outcomes, and early results. Innovations (Phila) 2014; 9: 292-296.

15. Yang M, Yao M, Wang G, Xiao C, Wu Y, Zhang H, Gao C. Comparison of postoperative quality of life for patients who undergo atrial myxoma excision with robotically assisted versus conventional surgery. J Thorac Cardiovasc Surg 2015; 150: 152-157.

16. Yanagawa F, Perez M, Bell T, Grim R, Martin J, Ahuja V. Critical outcomes in nonrobotic vs robotic assisted cardiac surgery. JAMA Surg 2015; 150: 771-777.

17. Bernstein WK, Walker A. Anesthetic issues for robotic cardiac surgery. Ann Card Anaesth 2015; 18: 58-68.

18. Wehman B, Lehr EJ, Lahiji K, Lee JD, Kon ZN, Jeudy J, Griffith BP, Bonatti J. Patient anatomy predicts operative time in robotic totally endoscopic coronary artery bypass surgery. Interact Cardiovasc Thorac Surg 2014; 19: 572-576.

19. Escoto A, Trejos AL, Patel RV, Goela A, Kiaii B. Anatomy-based eligibility measure for robotic assisted bypass surgery. Innovations (Phila) 2014; 9: 349-353.

20. Bachinsky WB, Abdelsalam M, Boga G, Kiljanek L, Mumtaz M, McCarty C. Comparative study of same sitting hybrid coronary artery revascularization versus off-pump coronary artery bypass in multivessel coronary artery disease. J Interv Cardiol 2012; 25: 460-8.

21. Jones B, Desai P, Poston R. Establishing the case for minimally invasive, ro botic assisted CABG in the treatment of multivessel coronary artery disease. Heart Surg Forum 2009; 12: E147-E149.

22. Wintergreen Research Inc., Cardiac Surgical Robots: Market Shares, Strategies, and Forecasts, Worldwide, 2015-2021, 2015 